\title{
Streptomyces herbaceus sp. nov., Streptomyces incanus sp. nov. and Streptomyces pratens sp. nov., isolated from the soil of a hay meadow
}

\author{
Correspondence \\ Michael Goodfellow \\ m.goodfellow@ncl.ac.uk
}

\author{
Byung-Yong Kim, ${ }^{1}$ Xiaoying Rong, ${ }^{2}$ Tiago D. Zucchi, ${ }^{1,3}$ \\ Avinash N. V. Bonda, ${ }^{1}$ Ying Huang ${ }^{2}$ and Michael Goodfellow ${ }^{1}$ \\ ${ }^{1}$ School of Biology, University of Newcastle, Newcastle upon Tyne NE1 7RU, UK \\ ${ }^{2}$ State Key Laboratory of Microbial Resources, Institute of Microbiology, \\ Chinese Academy of Sciences, Beijing 100101, PR China \\ ${ }^{3}$ Departamento de Entomologia \& Acarologia, ESALQ, Universidade de São Paulo, \\ 13418-900 Piracicaba, Brazil
}

\begin{abstract}
The taxonomic positions of three streptomycetes isolated from a soil sample from a hay meadow were determined using a polyphasic approach. The isolates had chemical and morphological properties typical of the genus Streptomyces and, in phylogenetic analyses based on 16S rRNA gene sequences, formed a distinct subclade that was most closely related to the Streptomyces prasinus subclade. DNA-DNA relatedness studies showed that the novel strains belonged to three different genomic species. The novel strains could be distinguished from one another and from the type strains of the species classified in the $S$. prasinus subclade using a combination of genotypic and phenotypic properties. On the basis of these data, it is proposed that the novel strains be assigned to the genus Streptomyces as Streptomyces herbaceus sp. nov., Streptomyces incanus sp. nov. and Streptomyces pratens sp. nov., with BK119 ${ }^{\top}$ (=KACC $21001^{\top}=$ CGMCC $\left.4.5797^{\top}\right)$, BK128 ${ }^{\top}\left(=\right.$ KACC $21002^{\top}=$ CGMCC $\left.4.5799^{\top}\right)$ and BK138 $\left(=\right.$ KACC $20904^{\top}=$ CGMCC $\left.4.5800^{\top}\right)$ as the respective type strains.
\end{abstract}

The discovery that the genomes of streptomycetes contain a large number of gene clusters that encode secondary metabolites (Bentley et al., 2002; Ikeda et al., 2003; Ohnishi et al., 2008) underlines the importance of these organisms as sources of novel and clinically significant bioactive compounds, notably antibiotics (Goodfellow \& Fiedler, 2010). Another remarkable feature of the genus Streptomyces is the large number of described species it contains: nearly 600 at the time of writing (Euzéby, 2011). The subgeneric classification of the genus, while complex, has been clarified by the application of genotypic and phenotypic procedures (Goodfellow et al., 2007; Rong \& Huang, 2010) that have also been used to circumscribe novel species isolated from clinical (Quintana et al., 2008) and environmental sources (Nagai et al., 2011; Zucchi et al., 2012). In the present polyphasic study, strains $\mathrm{BK} 119^{\mathrm{T}}, \mathrm{BK} 128^{\mathrm{T}}$ and $\mathrm{BK} 138^{\mathrm{T}}$ were isolated from the soil of a hay meadow and shown to represent three novel Streptomyces species.

The GenBank/EMBL/DDBJ accession numbers for the 16S rRNA gene sequences of Streptomyces herbaceus BK $119^{\top}$, Streptomyces incanus BK128 ${ }^{\top}$ and Streptomyces pratens BK138 ${ }^{\top}$ are FR692091, FR692095 and FR692098, respectively.

A supplementary table is available with the online version of this paper.
Strains $\mathrm{BK} 119^{\mathrm{T}}, \mathrm{BK} 128^{\mathrm{T}}$ and $\mathrm{BK} 138^{\mathrm{T}}$ were isolated on starch-casein agar (Küster \& Williams, 1964) supplemented with cycloheximide and nystatin (each at $25 \mu \mathrm{g} \mathrm{m}{ }^{-1}$ ), after incubation at $28{ }^{\circ} \mathrm{C}$ for 21 days. They came from a soil sample collected from plot 6 of the Palace Leas hay meadow (Atalan et al., 2000) at Cockle Park Experimental Farm, Ulgham, Morpeth, Northumberland, UK. The organisms were maintained on oatmeal agar slopes [International Streptomyces Project (ISP) medium 3; Shirling \& Gottlieb, 1966] at $4{ }^{\circ} \mathrm{C}$ and also as mixtures of mycelial fragments and spores in $20 \%(\mathrm{v} / \mathrm{v})$ glycerol at $-80{ }^{\circ} \mathrm{C}$. Biomass for the chemotaxonomic and molecular systematic studies was grown in shake flasks of glucose-yeast extract-malt extract broth (ISP medium 2; Shirling \& Gottlieb, 1966) at $28{ }^{\circ} \mathrm{C}$ for 7 days, harvested by centrifugation and then washed twice in distilled water; biomass for the chemotaxonomic studies was freeze-dried.

The phylogenetic positions of the three novel strains were determined by $16 \mathrm{~S}$ rRNA gene sequence analysis. Genomic DNA was extracted from the biomass preparations, and PCR amplification and 16S rRNA gene sequencing were achieved, using the procedures described by Kim et al. (2010). The resultant, almost complete 16S rRNA gene sequences (1458-1460 nt) were aligned manually against 
corresponding sequences of representatives of the genus Streptomyces, using the MEGA 3.0 software package (Kumar et al., 2004). Phylogenetic trees were inferred by using the maximum-parsimony (Fitch, 1971), minimum-evolution (Rzhetsky \& Nei, 1992) and neighbour-joining (Saitou \& Nei, 1987) algorithms. The Jukes \& Cantor (1969) model was used to generate evolutionary distance matrices for the neighbour-joining data. The resultant tree topologies were evaluated by bootstrap analysis (Felsenstein, 1985) based on 1000 resampled datasets, again using MEGA 3.0. The $16 \mathrm{~S}$ rRNA gene sequence of Streptacidiphilus albus $\mathrm{JL}^{2} 3^{\mathrm{T}}$ was used as the outgroup for each of the trees (Fig. 1).

The three novel strains formed a distinct subclade in each of the constructed trees, in a clustering that was supported by moderate bootstrap values (Fig. 1). The two most closely related strains, BK119 $9^{\mathrm{T}}$ and $\mathrm{BK} 128^{\mathrm{T}}$, showed a $16 \mathrm{~S}$ rRNA gene sequence similarity of $99.4 \%$, a value that corresponded to eight nucleotide differences over 1427 locations. Strain $\mathrm{BK} 138^{\mathrm{T}}$ showed a $16 \mathrm{~S}$ rRNA gene sequence similarity of $99.0 \%$ with both strain $\mathrm{BK} 119^{\mathrm{T}}$ and strain $\mathrm{BK} 128^{\mathrm{T}}$, a value equivalent to a difference of either 14 or $15 \mathrm{nt}$. The subclade formed by the three novel strains was most closely related to the Streptomyces prasinus subclade (the status of which was supported by all three treeing algorithms and by very high bootstrap values; Fig. 1). These two subclades united to form a distinct branch, the taxonomic integrity of which was also underpinned by all of the algorithms and by a high bootstrap value. The novel strains appeared most closely related to Streptomyces hirsutus NBRC $12786^{\mathrm{T}}$, with $16 \mathrm{~S}$ rRNA gene sequence similarities (98.4-98.6\%) that corresponded to differences of 20-25 nt. Of the three novel isolates, strain BK119 ${ }^{\mathrm{T}}$ was found to be the one most closely related to S. hirsutus NBRC $12786^{\mathrm{T}}$.

The level of DNA-DNA relatedness between the novel strains was investigated, in duplicate, by using the fluorometric microplate method of Ezaki et al. (1989) with the modifications described by $\mathrm{He}$ et al. (2005). The thermal denaturation method described by Gonzalez \& Saiz-Jimenez (2002) was used to estimate genomic DNA $\mathrm{G}+\mathrm{C}$ contents. The highest level of DNA-DNA relatedness, $45.6 \% \pm 0.8 \%$, was found between strains $\mathrm{BK} 119^{\mathrm{T}}$ and $\mathrm{BK} 138^{\mathrm{T}}$. The corresponding values between these two strains and strain $\mathrm{BK} 128^{\mathrm{T}}$ were $20.8 \pm 2.2 \%$ and $24.5 \pm$ $0.1 \%$, respectively. As the level of DNA-DNA relatedness observed between any two of the novel strains fell well below the $70 \%$ cut-off point recommended for the delineation of

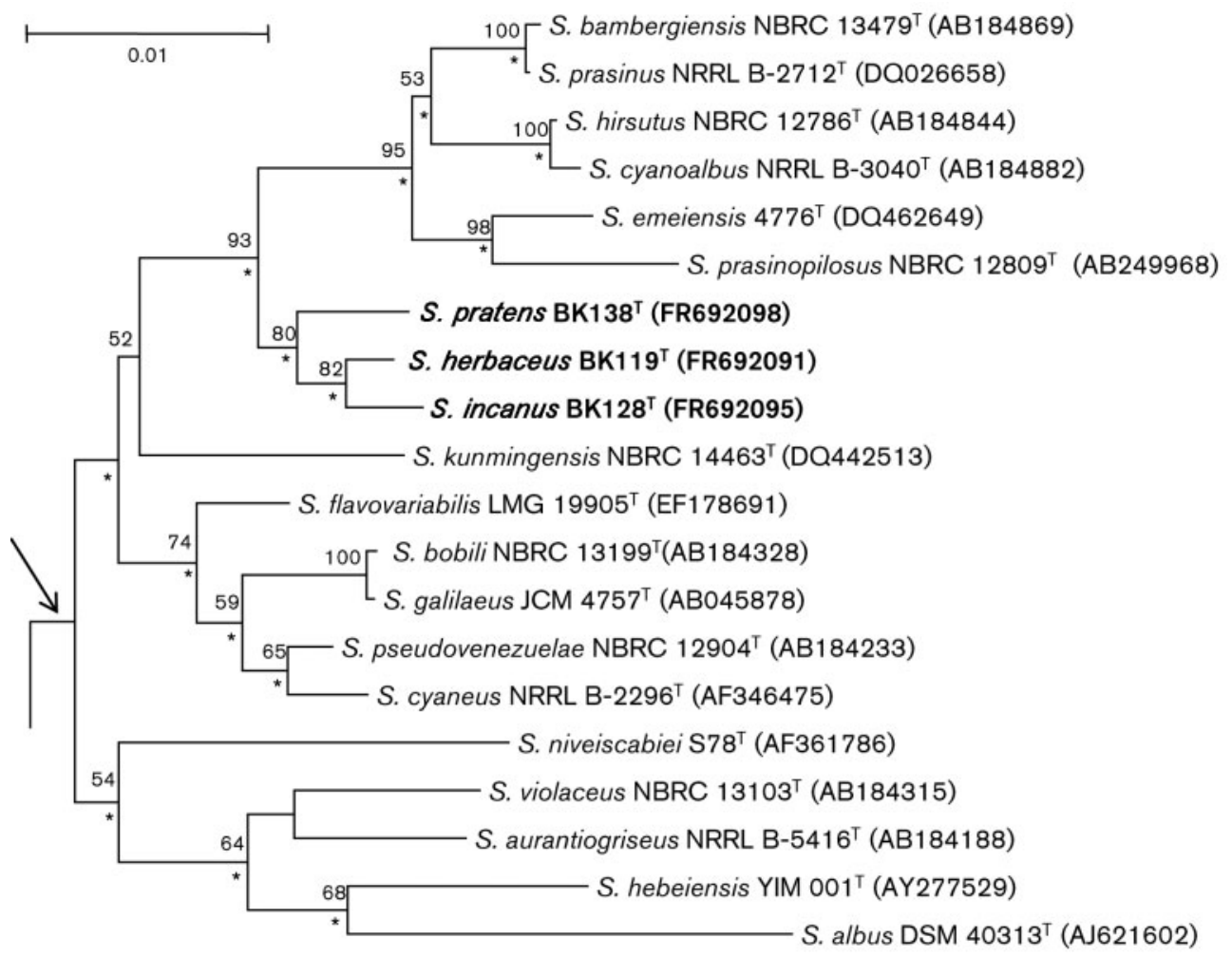

Fig. 1. Neighbour-joining tree based on nearly complete $16 \mathrm{~S}$ rRNA gene sequences (1418-1434 bp), showing the relationships between strains $\mathrm{BK} 119^{\top}, \mathrm{BK} 128^{\top}$ and $\mathrm{BK} 138^{\top}$ and between them and the type strains of related Streptomyces species. Asterisks indicate branches of the tree that were also recovered with the maximum-parsimony and minimum-evolution tree-making algorithms. Only bootstrap values $>50 \%$, expressed as percentages of 1000 replications, are shown at branch points. The arrow indicates the inferred root position. Bar, 0.01 substitution per nucleotide position. 
genomic species (Wayne et al., 1987), the novel strains apparently represented three different genomic species. The genomic DNA G + C contents of strains BK119 ${ }^{\mathrm{T}}, \mathrm{BK} 128^{\mathrm{T}}$ and $\mathrm{BK} 138^{\mathrm{T}}$ were $70.2,69.2$ and $73.2 \mathrm{~mol} \%$, respectively.

The novel strains were examined for the chemical markers considered to be typical of the genus Streptomyces. Standard procedures were used to determine the predominant menaquinones (Collins et al., 1985), muramic acid type (Uchida et al., 1999), mycolic acids (Minnikin et al., 1980), diagnostic whole-cell sugars (Hasegawa et al., 1983) and isomers of diaminopimelic acid (Hasegawa et al., 1983), using appropriate controls. Fatty acids were extracted from the strains, methylated, analysed by gas chromatography (6890; Hewlett Packard) and identified using version 5 of the Sherlock Microbial Identification System (MIDI) and the ACTINO database (Sasser, 1990).

When cultivated in ISP2 broth, all three novel strains contained major amounts of LL-diaminopimelic acid but lacked characteristic sugars in whole-organism hydrolysates (wall chemotype I, sensu Lechevalier \& Lechevalier, 1970). They all possessed $\mathrm{N}$-acetylated muramic acid, and all had hexa- and octa-hydrogenated menaquinones with nine isoprene units (MK-9 $\left[\mathrm{H}_{6}, \mathrm{H}_{8}\right]$ ) as predominant isoprenologues, in ratios of $1: 3,1: 1$ and $4: 3$, respectively. The cellular fatty acid profiles consisted mainly of saturated straight-chain and iso- and anteiso-branched-chain components (Table S1, available in IJSEM Online) and were of the 2c fatty acid type (sensu Kroppenstedt, 1985). None of the strains contained mycolic acids. All of these properties support the classification of all three novel strains in the genus Streptomyces (Lechevalier \& Lechevalier, 1970; Manfio et al., 1995, 2003; Anderson \& Wellington, 2001).

The novel strains were examined for cultural and morphological features following growth, for 3 weeks at $28{ }^{\circ} \mathrm{C}$, on ISP 2, ISP 3, inorganic salts-starch (ISP 4), glycerolasparagine (ISP 5), tyrosine (ISP 7) and modified Bennett's agars (Jones, 1949; Shirling \& Gottlieb, 1966). Spore arrangement and spore surface ornamentation were observed by examining gold-coated, dehydrated preparations from the ISP3 plates, using a scanning electron microscope (Stereoscan 240; Cambridge). On their aerial mycelia, strains $\mathrm{BK} 119^{\mathrm{T}}$ and $\mathrm{BK} 138^{\mathrm{T}}$ formed straight to flexuous chains
(Rectiflexibiles) of spiny and smooth-surfaced spores, respectively, whereas strain $\mathrm{BK} 128^{\mathrm{T}}$ produced spiral chains of smooth-surfaced spores (Fig. 2). The cultural characteristics of the strains are summarized in Table 1.

The novel strains were also examined for a range of phenotypic properties, using the media and methods described by Williams et al. (1983). The results were compared with those from the same tests carried out on the type strains of species classified in the $S$. prasinus subclade (Sun et al., 2007). The novel strains could be distinguished from each other, and from the type strains of the species forming the $S$. prasinus subclade, using a combination of phenotypic features (Table 2). For example, strains $\mathrm{BK} 128^{\mathrm{T}}$ and $\mathrm{BK} 138^{\mathrm{T}}$, unlike strain $\mathrm{BK} 119^{\mathrm{T}}$, formed smooth-surfaced spores, degraded adenine and hypoxanthine, and grew on dextrin, myo-inositol and methyl $\alpha$ D-glucopyranoside. Similarly, strains BK128 ${ }^{\mathrm{T}}$ and BK $138^{\mathrm{T}}$ can be readily separated since, of these two strains, only strain $\mathrm{BK} 128^{\mathrm{T}}$ degraded elastin, grew on L-arabinose, Dribose and D-sorbose as sole carbon sources, and was resistant to rifampicin (at $16 \mu \mathrm{g} \mathrm{ml}^{-1}$ ) and lysozyme (at $0.05 \%, \mathrm{w} / \mathrm{v})$. Strain BK $119^{\mathrm{T}}$ was also resistant to rifampicin and lysozyme. All three novel strains were susceptible to ( $\mu \mathrm{g}$ $\mathrm{ml}^{-1}$, unless indicated otherwise) gentamicin sulphate (8), kanamycin sulphate (8) and streptomycin sulphate (4) but resistant to ampicillin (4), clindamycin (8), ciprofloxacin (2), lincomycin hydrochloride (8), tetracycline hydrochloride (8) and penicillin $\mathrm{G}\left(2 \mathrm{IU} \mathrm{ml}^{-1}\right)$. In addition, all three novel strains, unlike the type strains of the species forming the $S$. prasinus subclade, degraded xanthine.

On the basis of the genotypic and phenotypic data, the three novel strains can be distinguished both from one another and from their nearest phylogenetic neighbours. Strains $\mathrm{BK} 119^{\mathrm{T}}, \mathrm{BK} 128^{\mathrm{T}}$ and $\mathrm{BK} 138^{\mathrm{T}}$ therefore represent three novel Streptomyces species, for which the names Streptomyces herbaceus sp. nov., Streptomyces incanus sp. nov. and Streptomyces pratens sp. nov., respectively, are proposed.

\section{Description of Streptomyces herbaceus sp. nov.}

Streptomyces herbaceus (her.ba'ce.us. L. masc. adj. herbaceus grass-coloured, grass-green, referring to the green colour of the aerial mycelium).
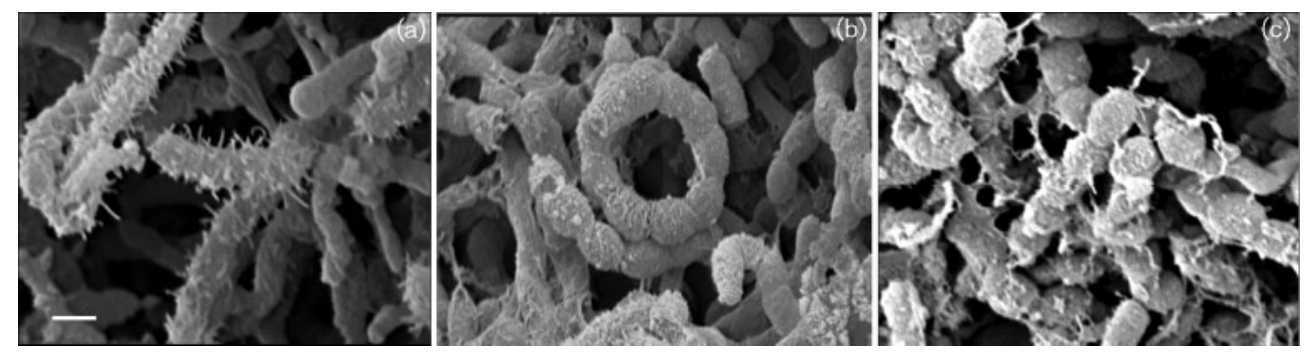

Fig. 2. Scanning electron micrographs of strains $B K 119^{\top}$ (a), BK128 $8^{\top}$ (b) and $B K 138^{\top}$ (c) showing the spore arrangement and spore ornamentation following growth on oatmeal agar at $28{ }^{\circ} \mathrm{C}$ for 3 weeks. Bar, $2 \mu \mathrm{m}$. 


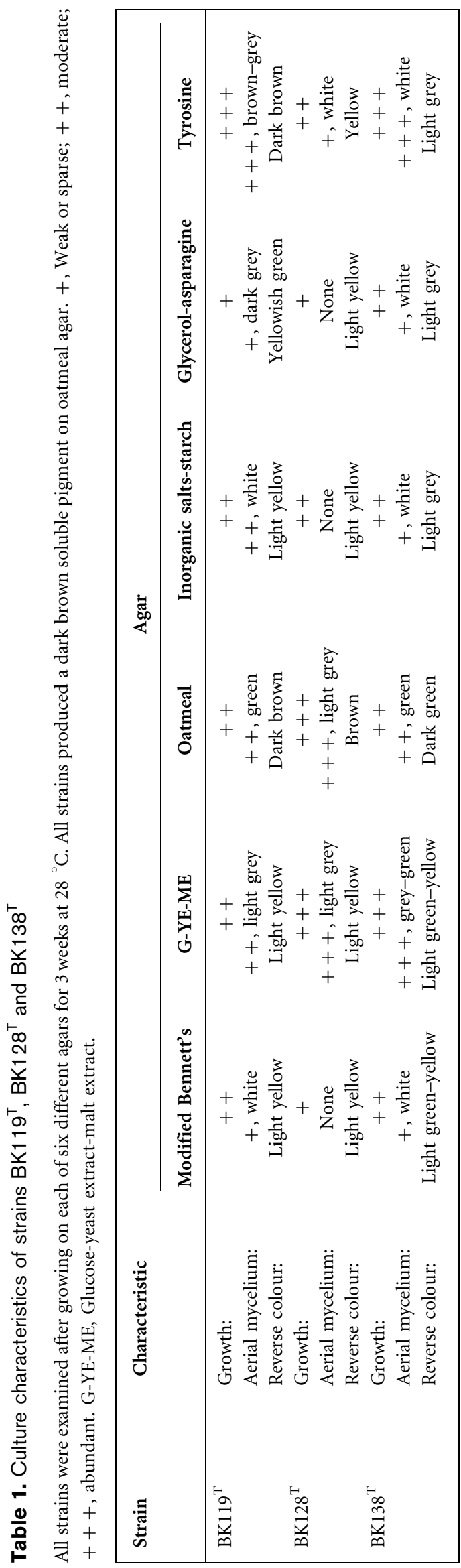

Aerobic, Gram-staining-positive, non-acid-alcohol-fast actinomycete that, on oatmeal agar, forms a branched substrate mycelium that bears aerial hyphae that differentiate into straight chains of spiny-surfaced spores $(0.7-0.8 \times 0.7-$ $0.9 \mu \mathrm{m})$. Grows at $10-37^{\circ} \mathrm{C}$ and at $\mathrm{pH} 5.0-10.0$ but not in the presence of $7.0 \%(\mathrm{w} / \mathrm{v}) \mathrm{NaCl}$. Degrades casein, DNA, gelatin, starch and L-tyrosine but not chitin, guanine, tributyrin or uric acid. L-Arabitol, maltose, melibiose and D-sorbitol are used as sole carbon sources for energy and growth (at $1 \%, \mathrm{w} / \mathrm{v})$ but not oxalic acid (at $0.1 \%, \mathrm{w} / \mathrm{v})$. Additional properties are cited in the text and in Tables 1 and 2. Chemotaxonomic properties are typical of the genus Streptomyces.

The type strain, BK119 $\left(=\right.$ KACC $21001^{\mathrm{T}}=\mathrm{CGMCC}$ $4.5797^{\mathrm{T}}$ ), was isolated from the soil of a hay meadow. The genomic DNA G+C content of the type strain is $70.2 \mathrm{~mol} \%$. The species description is based on a single strain and hence serves as the description of the type strain.

\section{Description of Streptomyces incanus sp. nov.}

Streptomyces incanus (in.ca' nus. L. masc. adj. incanus light grey, referring to the colour of the aerial mycelium).

Aerobic, Gram-staining-positive, non-acid-alcohol-fast actinomycete that, on oatmeal agar, forms an extensively branched substrate mycelium bearing aerial hyphae that differentiate into spiral or hooked spore chains of smoothsurfaced spores $(0.8-0.9 \times 0.8-0.9 \mu \mathrm{m})$. Grows at $10-37{ }^{\circ} \mathrm{C}$ and at $\mathrm{pH} 5.0-10.0$ but not in the presence of $7.0 \%(\mathrm{w} / \mathrm{v})$ $\mathrm{NaCl}$. Degrades casein, DNA, gelatin, starch, L-tyrosine and uric acid but not cellulose, chitin, guanine or tributyrin. LArabitol, maltose, melibiose and D-sorbitol (at 1\%,w/v) are used as sole carbon sources for energy and growth but D-salicin (at 1\%, w/v) or oxalic acid (at $0.1 \%, \mathrm{w} / \mathrm{v})$ are not. Additional properties are cited in the text and in Tables 1 and 2. Chemotaxonomic properties are typical of the genus Streptomyces.

The type strain, BK128 ${ }^{\mathrm{T}}$ (=KACC $21002^{\mathrm{T}}=\mathrm{CGMCC}$ $4.5799^{\mathrm{T}}$ ), was isolated from the soil of a hay meadow. The genomic DNA G + C content of the type strain is $69.2 \mathrm{~mol} \%$. The species description is based on a single strain and hence serves as the description of the type strain.

\section{Description of Streptomyces pratens sp. nov.}

Streptomyces pratens (pra'tens. L. masc. adj. pratens green, meadow-green, referring to the green colour of the aerial and substrate mycelium).

Aerobic, Gram-staining-positive, non-acid-alcohol-fast actinomycete that, on oatmeal agar, forms a branched substrate mycelium bearing aerial hyphae that differentiate into straight to flexuous chains of smooth-surfaced spores $(0.7-0.8 \times 0.7-$ $0.8 \mu \mathrm{m})$. Grows at $10-37{ }^{\circ} \mathrm{C}$ and at $\mathrm{pH} 5.0-9.0$ but not in the presence of $7.0 \%(\mathrm{w} / \mathrm{v}) \mathrm{NaCl}$. Degrades casein, DNA, gelatin, starch and L-tyrosine but not cellulose, guanine, tributyrin or uric acid. L-Arabitol, maltose, melibiose and D-sorbitol are 
Table 2. Phenotypic characteristics of strains $\mathrm{BK} 119^{\top}, \mathrm{BK} 128^{\top}$ and $\mathrm{BK} 138^{\top}$ and their closest phylogenetic relatives in the genus Streptomyces

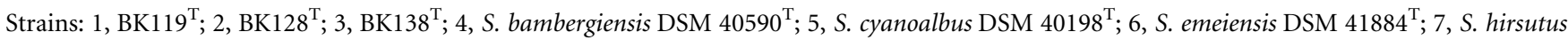
DSM $40095^{\mathrm{T}}$; 8, S. prasinopilosus DSM $40098^{\mathrm{T}}$; 9, S. prasinus DSM $40099^{\mathrm{T}}$. Data for the reference strains in the S. prasinus subclade were taken from Sun et al. (2007). All of the strains were positive for the assimilation of cellobiose, D-fructose, D-galactose, D-glucose, D-mannose, L-rhamnose, sodium citrate, sucrose, trehalose and D-xylose and negative for the degradation of guanine. +, Positive; - , negative; w, weakly positive.

\begin{tabular}{|c|c|c|c|c|c|c|c|c|c|}
\hline Characteristic & 1 & 2 & 3 & 4 & 5 & 6 & 7 & 8 & 9 \\
\hline Aerial spore mass colour on oatmeal agar & Green & Light grey & $\begin{array}{c}\text { Greyish } \\
\text { green }\end{array}$ & Green & $\begin{array}{c}\text { Green or } \\
\text { grey }\end{array}$ & $\begin{array}{c}\text { Greyish } \\
\text { green }\end{array}$ & Green & Green & Green \\
\hline Spore surface & Spiny & Smooth & Smooth & Hairy & Spiny & Spiny & Spiny & Hairy & Spiny \\
\hline Production of diffusible pigments & + & + & + & + & - & - & - & - & - \\
\hline \multicolumn{10}{|l|}{ Degradation of: } \\
\hline Adenine & - & + & + & - & + & + & - & - & - \\
\hline Aesculin & + & + & + & - & + & + & + & + & - \\
\hline Elastin & - & + & - & + & + & + & + & + & + \\
\hline Hypoxanthine & - & + & + & - & - & - & - & - & - \\
\hline Tween 20 & - & - & - & $\mathrm{w}$ & + & + & + & + & + \\
\hline Tween 80 & - & - & - & + & + & + & + & + & + \\
\hline Xanthine & + & + & + & - & - & - & - & - & - \\
\hline \multicolumn{10}{|l|}{ Growth on sole carbon sources $(1.0 \%, \mathrm{w} / \mathrm{v})$ : } \\
\hline L-Arabinose & - & + & - & $\mathrm{w}$ & + & + & + & + & + \\
\hline Dextrin & - & + & + & + & + & + & - & + & + \\
\hline myo-Inositol & - & + & + & + & + & + & + & - & + \\
\hline Inulin & + & + & + & + & + & - & + & + & + \\
\hline Methyl $\alpha$-D-glucopyranoside & - & + & + & - & + & - & $\mathrm{W}$ & w & + \\
\hline Raffinose & + & + & + & + & - & + & + & - & - \\
\hline D-Ribose & - & + & - & - & - & + & - & - & - \\
\hline D-Sorbose & - & + & - & + & + & - & + & + & + \\
\hline
\end{tabular}

used as sole carbon sources for energy and growth (at $1 \%, \mathrm{w} /$ v) but not oxalic acid (at $0.1 \%, \mathrm{w} / \mathrm{v}$ ). Additional properties are cited in the text and in Tables 1 and 2. Chemotaxonomic properties are typical of the genus Streptomyces.

The type strain, BK $138^{\mathrm{T}}$ (=KACC $20904^{\mathrm{T}}=\mathrm{CGMCC}$ $4.5800^{\mathrm{T}}$ ), was isolated from the soil of a hay meadow. The genomic DNA $\mathrm{G}+\mathrm{C}$ content of the type strain is $73.2 \mathrm{~mol} \%$. The species description is based on a single strain and hence serves as the description of the type strain.

\section{Acknowledgements}

B.-Y.K. gratefully acknowledges receipt of an Overseas Research Scholarship from Newcastle University. T.D.Z. is grateful to the Conselho Nacional de Desenvolvimento Científico e Tecnológico for a fellowship to study in the UK (grant 201066/2009-2). The authors are also indebted to Professor Jean Euzéby for suggesting names for the novel species.

\section{References}

Anderson, A. S. \& Wellington, E. M. H. (2001). The taxonomy of Streptomyces and related genera. Int J Syst Evol Microbiol 51, 797-814.

Atalan, E., Manfio, G. P., Ward, A. C., Kroppenstedt, R. M. \& Goodfellow, M. (2000). Biosystematic studies on novel streptomycetes from soil. Antonie van Leeuwenhoek 77, 337-353.
Bentley, S. D., Chater, K. F., Cerdeño-Tárraga, A.-M., Challis, G. L., Thomson, N. R., James, K. D., Harris, D. E., Quail, M. A., Kieser, H. \& other authors (2002). Complete genome sequence of the model actinomycete Streptomyces coelicolor A3(2). Nature 417, 141-147.

Collins, M. D., Goodfellow, M., Minnikin, D. E. \& Alderson, G. (1985). Menaquinone composition of mycolic acid-containing actinomycetes and some sporoactinomycetes. J Appl Bacteriol 58, 77-86.

Euzéby, J. P. (2011). List of Prokaryotic names with Standing in Nomenclature. http://www.bacterio.cict.fr/.

Ezaki, T., Hashimoto, Y. \& Yabuuchi, E. (1989). Fluorometric deoxyribonucleic acid-deoxyribonucleic acid hybridization in microdilution wells as an alternative to membrane filter hybridization in which radioisotopes are used to determine genetic relatedness among bacterial strains. Int J Syst Bacteriol 39, 224-229.

Felsenstein, J. (1985). Confidence limits on phylogenies: an approach using the bootstrap. Evolution 39, 783-791.

Fitch, W. M. (1971). Toward defining the course of evolution: minimum change for a specific tree topology. Syst Zool 20, 406-416.

Gonzalez, J. M. \& Saiz-Jimenez, C. (2002). A fluorimetric method for the estimation of $\mathrm{G}+\mathrm{C}$ mol\% content in microorganisms by thermal denaturation temperature. Environ Microbiol 4, 770-773.

Goodfellow, M. \& Fiedler, H. P. (2010). A guide to successful bioprospecting: informed by actinobacterial systematics. Antonie van Leeuwenhoek 98, 119-142.

Goodfellow, M., Kumar, Y., Labeda, D. P. \& Sembiring, L. (2007). The Streptomyces violaceusniger clade: a home for streptomycetes with rugose ornamented spores. Antonie van Leeuwenhoek 92, 173199. 
Hasegawa, T., Takizawa, M. \& Tanida, S. (1983). A rapid analysis for chemical grouping of aerobic actinomycetes. J Gen Appl Microbiol 29, 319-322.

He, L., Li, W., Huang, Y., Wang, L., Liu, Z., Lanoot, B., Vancanneyt, M. \& Swings, J. (2005). Streptomyces jietaisiensis sp. nov., isolated from soil in northern China. Int J Syst Evol Microbiol 55, 1939-1944.

Ikeda, H., Ishikawa, J., Hanamoto, A., Shinose, M., Kikuchi, H., Shiba, T., Sakaki, Y., Hattori, M. \& Omura, S. (2003). Complete genome sequence and comparative analysis of the industrial microorganism Streptomyces avermitilis. Nat Biotechnol 21, 526-531.

Jones, K. L. (1949). Fresh isolates of actinomycetes in which the presence of sporogenous aerial mycelia is a fluctuating characterstic. J Bacteriol 57, 141-145.

Jukes, T. H. \& Cantor, C. R. (1969). Evolution of protein molecules. In Mammalian Protein Metabolism, vol. 3, pp. 21-132. Edited by $\mathrm{H}$. N. Munro. New York: Academic Press.

Kim, B. Y., Stach, J. E. M., Weon, H. Y., Kwon, S. W. \& Goodfellow, M. (2010). Dactylosporangium luridum sp. nov., Dactylosporangium luteum sp. nov. and Dactylosporangium salmoneum sp. nov., nom. rev., isolated from soil. Int J Syst Evol Microbiol 60, 1813-1823.

Kroppenstedt, R. M. (1985). Fatty acid and menaquinone analysis of actinomycetes and related organisms. In Chemical Methods in Bacterial Systematics (Society for Applied Bacteriology Technical Series vol. 20), pp. 173-199. Edited by M. Goodfellow \& D. E. Minnikin. New York: Academic Press.

Kumar, S., Tamura, K. \& Nei, M. (2004). MEGA3: integrated software for molecular evolutionary genetics analysis and sequence alignment. Brief Bioinform 5, 150-163.

Küster, E. \& Williams, S. T. (1964). Selection of media for isolation of streptomycetes. Nature 202, 928-929.

Lechevalier, M. P. \& Lechevalier, H. A. (1970). Chemical composition as a criterion in the classification of aerobic actinomycetes. Int J Syst Bacteriol 20, 435-443.

Manfio, G., Zakrzewska-Czerwinska, J., Atalan, E. \& Goodfellow, M. (1995). Towards minimal standards for description of Streptomyces species. Biotekhnologiya 7, 242-283.

Manfio, G. P., Atalan, E., Zakrzewska-Czerwinska, J., Mordarski, M., Rodríguez, C., Collins, M. D. \& Goodfellow, M. (2003). Classification of novel soil streptomycetes as Streptomyces aureus sp. nov., Streptomyces laceyi $\mathrm{sp}$. nov. and Streptomyces sanglieri sp. nov. Antonie van Leeuwenhoek 83, 245-255.

Minnikin, D. E., Hutchinson, I. G., Caldicott, A. B. \& Goodfellow, M. (1980). Thin-layer chromatography of methanolysates of mycolic acid-containing bacteria. J Chromatogr A 188, 221-233.
Nagai, A., Khan, S. T., Tamura, T., Takagi, M. \& Shin-ya, K. (2011). Streptomyces aomiensis sp. nov., isolated from a soil sample using the membrane-filter method. Int J Syst Evol Microbiol 61, 947-950.

Ohnishi, Y., Ishikawa, J., Hara, H., Suzuki, H., Ikenoya, M., Ikeda, H., Yamashita, A., Hattori, M. \& Horinouchi, S. (2008). Genome sequence of the streptomycin-producing microorganism Streptomyces griseus IFO 13350. J Bacteriol 190, 4050-4060.

Quintana, E. T., Wierzbicka, K., Mackiewicz, P., Osman, A., Fahal, A. H., Hamid, M. E., Zakrzewska-Czerwinska, J., Maldonado, L. A. \& Goodfellow, M. (2008). Streptomyces sudanensis sp. nov., a new pathogen isolated from patients with actinomycetoma. Antonie van Leeuwenhoek 93, 305-313.

Rong, X. \& Huang, Y. (2010). Taxonomic evaluation of the Streptomyces griseus clade using multilocus sequence analysis and DNA-DNA hybridization, with proposal to combine 29 species and three subspecies as 11 genomic species. Int J Syst Evol Microbiol 60, 696-703.

Rzhetsky, A. \& Nei, M. (1992). A simple method for estimating and testing minimum-evolution trees. Mol Biol Evol 9, 945-967.

Saitou, N. \& Nei, M. (1987). The neighbor-joining method: a new method for reconstructing phylogenetic trees. Mol Biol Evol 4, 406425.

Sasser, M. (1990). Identification of bacteria by gas chromatography of cellular fatty acids, MIDI Technical Note 101. Newark, DE: MIDI Inc.

Shirling, E. B. \& Gottlieb, D. (1966). Methods for characterization of Streptomyces species. Int J Syst Bacteriol 16, 313-340.

Sun, W., Huang, Y., Zhang, Y.-Q. \& Liu, Z.-H. (2007). Streptomyces emeiensis sp. nov., a novel streptomycete from soil in China. Int J Syst Evol Microbiol 57, 1635-1639.

Uchida, K., Kudo, T., Suzuki, K. I. \& Nakase, T. (1999). A new rapid method of glycolate test by diethyl ether extraction, which is applicable to a small amount of bacterial cells of less than one milligram. J Gen Appl Microbiol 45, 49-56.

Wayne, L. G., Brenner, D. J., Colwell, R. R., Grimont, P. A. D., Kandler, O., Krichevsky, M. I., Moore, L. H., Moore, W. E. C., Murray, R. G. E. \& other authors (1987). International Committee on Systematic Bacteriology. Report of the ad hoc committee on reconciliation of approaches to bacterial systematics. Int J Syst Bacteriol 37, 463-464.

Williams, S. T., Goodfellow, M., Alderson, G., Wellington, E. M., Sneath, P. H. \& Sackin, M. J. (1983). Numerical classification of Streptomyces and related genera. J Gen Microbiol 129, 1743-1813.

Zucchi, T. D., Kim, B.-Y., Kshetrimayum, J. D., Weon, H.-Y., Kwon, S.-W. \& Goodfellow, M. (2012). Streptomyces brevispora sp. nov. and Streptomyces laculatispora sp. nov., actinomycetes isolated from soil. Int J Syst Evol Microbiol 62, 478-483. 